\title{
ANALISIS KESULITAN MATEMATIKA SISWA SMA/MA DALAM MENYELESAIKAN SOAL SETARA UN DI KABUPATEN MALUKU TENGAH
}

\author{
Muhammad Irfan Rumasoreng ${ }^{1)}$, Sugiman ${ }^{2)}$ \\ LB IAIN Ambon ${ }^{1)}$, Universitas Negeri Yogyakarta ${ }^{2)}$ \\ irfanlaturumasoreng@gmail.com ${ }^{1)}$, sugiman_uny@yahoo.com ${ }^{2)}$
}

\begin{abstract}
Abstrak
Tujuan penelitian ini adalah menentukan jenis kesulitan siswa SMA/MA Kabupaten Maluku Tengah dalam menyelesaikan soal setara UN dan faktor yang menyebabkannya. Pendekatan penelitian ini adalah kualitatif deskriptif. Populasi penelitian adalah 1819 siswa kelas XII SMA/MA Program IPA dari 53 sekolah di Kabupaten Maluku Tengah. Sampel berasal dari tujuh sekolah dengan jumlah siswa sebanyak 95 orang. Pengumpulan data dilakukan dengan menggunakan tes tulis berbentuk uraian dan dilengkapi dengan wawancara terhadap subjek untuk melacak jenis kesulitan; yakni kesulitan fakta, ketrampilan, konsep, dan prinsip serta faktor penyebabnya. Soal yang diujikan sebanyak 10 butir soal yang merupakan soal dengan daya serap rendah berdasarkan hasil UN tahun 2008 hingga 2011. Analisis data dilakukan dengan menghitung banyak kesulitan siswa yang didukung hasil tes dan wawancara, kemudian dilanjutkan dengan penarikan kesimpulan.Hasil penelitian menunjukkan kesulitan fakta tertinggi dialami sekolah strata rendah diikuti strata sedang kemudian strata tinggi. Urutan tingkat kesulitan tersebut juga terjadi dalam hal kesulitan ketrampilan, konsep, dan prinsip. Sedangkan faktor-faktor yang menyebabkan kesulitan berdasarkan hasil telaah terhadap jawaban siswa adalah siswa tidak mampu dalam hal penguasaan konsep, perpaduan antarkonsep, ketrampilan dalam menyelesaikan soal turunan dalam trigonometri dan teknik integral, penggunaan perbandingan trigonometri, penentuan banyaknya pilihan dalam menyelesaikan soal kombinasi, penentuan persamaan garis singgung lingkaran, penggunaan aturan kosinus dalam menentukan volume bangun ruang, penggunaan konsep limit baik bentuk aljabar maupun trigonometri, pembuatan model matematika, danpenentuan daerah asal suatu fungsi komposisi.
\end{abstract}

Kata kunci: kesulitan, fakta, konsep, ketrampilan, prinsip, Ujian Nasional SMA/MA.

\section{Abstract}

This study aims to identify the types of SMA/MA students' difficulties in doing a test equal to the National Examination (NE) in Central Maluku Regency and the underlying factors. This was a qualitative descriptive study. The research population comprised grade XII students of the Science Program in SMA/MA in Central Maluku Regency. The sample consisting of 95 students was selected from seven schools. The data were collected through a written essay test, complemented by interviews with the research subjects to trace the types of difficulties, namely those related to facts, skills, concepts, principles, and underlying factors. The test consisted of ten items with low absorption indices according to the results of the NEs from 2008 to 2011. The data analysis was carried out by counting the number of the students' difficulties, supported by the results of the test and interviews, followed by conclusion drawing. The results of the study show that the difficulties related to facts are faced by most schools in the low status, followed by those in the medium and high statuses. The difficulties related to skills are faced by most schools in the low status, followed by those in the medium and high statuses. The difficulties related to concepts are faced by most schools in the low status, followed by those in the medium and high statuses. The difficulties related to principles are faced by most schools in the low status, followed by those in the medium and high statuses. The factors underlying the difficulties based on the results of the analysis of students' answers are that they do not have capabilities in the concept mastery, the combination of several concepts, the skills in doing the derived items in trigonometry and integral technique, the use of trigonometry proportions, the determination of the number of choices in doing combination items, the determination of circle tangent equations, the use of cosine rules to determine the volume of a space figure, the use of the concept of limit in algebra and trigonometry forms, the making of mathematical models, and the determination of the domain of a composition function.

Keywords: difficulties, facts, concepts, skills, principles, National Examination for SMA/MA 


\section{PENDAHULUAN}

Dalam Ayat 1 Pasal 66 Peraturan Pemerintah No. 19 Tahun 2005, dijelaskan secara terpirinci bahwa hasil Ujian Nasional digunakan sebagai salah satu pertimbangan untuk (a) pemetaan mutu program dan/atau satuan pendidikan, (b) dasar seleksi masuk jenjang pendidikan berikutnya, (c) penentuan kelulusan peserta didik dari program dan/atau satuan pendidikan, dan (d) pembinaan dan pemberian bantuan kepada satuan pendidikan dalam upayanya untuk meningkatkan mutu pendidikan.

Peraturan Pemerintah tersebut sejalan dengan pendapat (Stecher, 2002; Sloane \& Kelly, 2003) menyatakan bahwa, ujian akhir dapat disebut sebagai "highstakes testing" karena memiliki dampak yang luas dalam sistem pendidikan. Ujian Nasional yang dilaksanakan pada setiap tahun untuk setiap jenjang dari SD sampai SMA dalam bentuk tes pilihan ganda selalu mengalami perubahan format dalam pelaksanaannya, hal ini dimaksud agar dapat mengurangi kecurangan dalam proses Ujian Nasional dan dapat meningkatkan prestasi belajar siswa dalam pengembangan ilmu pengetahuan dan teknologi.

Pada Ujian Nasional berdasarkan BSNP terdapat beberapa kompetensi yang selalu mengalami masalah di Kabupaten Maluku Tengah yakni (1) menentukan integral tak tentu fungsi trigonometri, (2) menghitung nilai perbandingan trigonometri sudut antar garis dan bidang pada bangun ruang, (3) menyelesaikan masalah yang berkaitan dengan kombinasi sederhana, (4) menentukan persamaan garis singgung lingkaran dengan syarat tertentu, (5) menentukan volume bangun ruang dengan menggunakan aturan sinus dan cosinus, (6) menentukan nilai limit fungsi aljabar, (7) menentukan integral tak tentu fungsi aljabar, (8) menentukan nilai limit fungsi trigonometri, (9) menyelesaikan masalah yang berkaitan dengan nilai maksimun dan minimum, dan (10) menentukan nilai hasil komposisi fungsi dari dua fungsi yang diketahui. Dari $10 \mathrm{kom}-$ petensi tersebut kompetensi "menentukan integral tak tentu fungsi trigonometri" termasuk yang paling rendah dalam ujian nasional.

Rendahnya daya serap pada Ujian Nasional tahun pelajaran 2010/2011 menunjukkan bahwa kesulitan siswa dalam menyelesaikan soal-soal yang diujikan sangat berfariasi, untuk mengetahui kesulitan siswa dan faktor penyebabnya difokuskan pada hal-hal yang disebabkan oleh kesalahan-kesalahan akibat dari kesulitan dalam menggunakan fakta, ketrampilan, memahami konsep dan menerapkan prinsip dalam menyelesaikan soal ujian nasional. Sebagaimana yang dikemukan oleh ahli belajar (learning theorist) Gagne (Bell, 1981, p.108), telah membagi objek-objek matematika, yaitu materi yang dipelajari siswa menjadi objek langsung dan objek tak langsung. Objek langsungnya adalah fakta, ketrampilan, konsep, dan prinsip (FKKP).

Konsep-konsep dalam matematika terorganisir secara sistematis, logis dan hirarkis dari yang paling sederhana ke yang kompleks. Pemahaman dan penguasaan suatu materi/konsep baru merupakan rekonstruksi dan aplikasi konsep-konsep pengetahuan yang sebelumnya dipelajari siswa (Romberg \& Kaput, 2009; Rose \& Arline, 2009; Goos, Stillman \& Vale, 2007; Ben-Zvi \& Hofstein, 1996; Skemp, 1971; Polya, 1981). Selanjutnya seseorang dikatakan memahami matematika apabila mampu menjelaskan konsep-konsep matematika dan fakta-fakta dalam bentuk sederhana serta mampu menghubungkannya secara logis antara fakta dan konsep yang berbeda (Alfeld, 2004; Dowker, 2004; Romberg \& Shafer, 2007; Bynner \& Parsons, 1997; Cawley, 1985)

Beberapa penelitian menyatakan bahwa penyebab kesulitan matematika siswa adalah akibat kesalahan hitung, prosedur yang keliru, ketrampilan mengitung dan membaca (Lewis, Hitch \& Walker, 1994; Gross-Tsur, Manor \& Shalev, 1996; Bzuka, Hein \& Neumarker, 2000, Jane \& Zakaria, 2012). Dalam penelitian yang lain meyebutkan bahwa terdapat dua macam kesulitan yang berkenaan dengan pertidaksamaan yakni kesulitan aritmetika dan ketiadaan pemaknaan serta pengaruh simbolisasi matematis terhadap kinerja siswa dalam menterjemahkan permasalahan dalam membuat persamaan matematika (Luna \& Fuscablo, 2002; Blanco \& Garrote, 2007)

Sementara itu, Bell (1981, p.402) menuturkan bahwa kesulitan matematika dalam memecahkan masalah matematika salah satunya disebabkan oleh kesulitan membaca permasalahan matematika yang dihadapi. Siswa cendrung bisa membaca langsung materi matematika dari buku, namun tidak mampu mamahami apa yang dibacanya. Bell (1981, p.408) menunjukkan cara terbaik untuk megidentifkasi penyebab kesulitan siswa adalah meminta siswa membaca permasalahan matematika dengan keras kemudian meminta siswa menginterpetasikan per kalimat.

Matematika sangat bermanfaat dalam kehidupan dan mendukung perkembangan bidang- 
bidang ilmu yang lain, seperti yang diungkapkan Muijs dan Reynalds (2005, p.212) berikut. Matematika sangatlah penting dan bukan sekedar aplikasi keterampilan dasar berhitung. Matematika juga merupakan sarana utama untuk mengembangkan pikiran logis pada anak-anak dan merupakan tingkatan yang tinggi pada keterampilan kognitif. Matematika juga memainkan peran utama pada disiplin ilmu yang lain, seperti fisika, teknik, dan statistik.

Kesulitan belajar matematika merupakan suatu rintangan, halangan, maupun kesukaran matematika yang meliputi banyak hal dan harus dihadapi siswa. Kesulitan belajar matematika siswa dapat berasal dari bermacam-macam sumber salah satunya adalah kognitif siswa (Kennedy, Tipps \& Johnson, 2008; Henson \& Eller, 1999).

Tujuan yang ingin dicapai dalam penelitian ini adalah untuk menganalisis jenis kesulitan apa saja yang dialami siswa SMA/MA di Kabupaten Maluku Tengah dalam menyelesaikan soal-soal matematika pada UN tahun pelajaran 2010/2011 dan faktor yang menyebabkan kesulitan siswa SMA/MA di Kabupaten Maluku Tengah dalam menyelesaikan soal-soal matematika pada UN tahun pelajaran 2010/2011. Dengan menganalisis kesulitan siswa dan faktor penyebabnya dapat meminimalisasi kesulitan siswa dalam menyelesaikan soal Ujian Nasional.

Hasil penelitian ini diharapkan dapat memberikan manfaat kepada (a) Guru, sebagai bahan masukan bagi guru matematika untuk dapat melaksanakan perbaikan dan lebih terarah terhadap materi-materi yang memiliki daya serap yang rendah dan (b) Siswa, sebagai acuan dalam mempersiapkan siswa menghadapi UN pada saat Kelas XII SMA/MA Program IPA. Khususnya sebagai masukan kepada Kepala Sekolah dan Kepala Dinas Pendidikan Nasional Kabupaten Maluku Tengah untuk melakukan pembinaan dalam rangka meningkatkan kualitas Ujian Nasional pada tahun berikutnya.

\section{METODE PENELITIAN}

\section{Jenis Penelitian}

Penelitian ini merupakan penelitian deskriptif karena bertujuan untuk mendeskripsikan kesulitan siswa SMA/MA Se-Kabupaten Malu$\mathrm{ku}$ Tengah dalam menyelesaikan soal-soal pada UN matematika tahun pelajaran 2010/2011. Ditinjau dari pendekatan analisisnya, penelitian ini terbagi atas dua yaitu: (1) pendekatan kuantitatif digunakan untuk mengetahui banyaknya kesulitan siswa/peserta tes dalam mengerjakan soal-soal yang diujikan dan untuk memilih subjek penelitian dan (2) pendekatan kualitatif digunakan untuk menentukan letak kesulitan siswa SMA dalam meyelesaikan soal-soal matematika berdasarkan kompotensi yang sulit tahun pelajaran 2011. Untuk memperjelas kesulitan siswa yang ditemukan melalui analisis jawaban, diadakan wawancara terhadap subjek. Wawancara didasarkan pada kesulitan dalam menyelesaikan soal yang ditemukan.

\section{Tempat dan Waktu Penelitian}

Penelitian ini dilaksanakan di Kabupaten Maluku Tengah Propinsi Maluku dan Waktu Penelitian selama 2 bulan mulai dari bulan Maret sampai Juli 2012

\section{Subjek Penelitian}

Subjek penelitian ini adalah siswa Kelas XII program IPA SMA/Sederajat di Kabupaten Maluku Tengah Propinsi Maluku yang berjumlah 1819 siswa. Jumlah sekolah SMA di Kabupaten Maluku Tengah adalah 53 sekolah terdiri dari 34 sekolah berstatus negeri dan 19 berstatus swasta.

Jumlah subjek yang sangat besar sehingga perlu dilakukan pengambilan sampel berdasarkan jumlah sekolah yang ada. Agar diperoleh sampel yang benar-benar mewakili populasi, maka dilakukan pengambilan sampel dilakukan dengan memperhatikan strata-strata dalam populasi. Pengambilan sampel dengan menggunakan teknik stratified proportional random sampling atau sampel acak proposional bersrata. Teknik tersebut merupakan gabungan dari stratified sampling (tekning sampling bertingkat) dan proportional sampling (teknik sampling proportional) dilanjutkan dengan random sampling (teknik sampling acak)

Langkah-langkah penentuan ukuran sampel (Riduwan, 2010, p.67) adalah sebagai berikut: Pertama, menggunakan rumus penentuan ukuran sampel yang dipakai.

$$
n=\frac{N}{N d^{2}+1}
$$

$\mathrm{n}=$ ukuran sampel

$\mathrm{N}=$ Banyaknya siswa

$d^{2}=$ tingkat presisi

Berdasarkan rumus penentuan ukuran sampel diperoleh jumlah ukuran sampel dengan menggunakan tingkat presisi $10 \%$ yaitu. 


$$
n=\frac{1819}{1819(0.1)^{2}+1}=94,78 \approx 95,
$$

maka diperoleh ukuran sampel sebesar 95 .

Kedua, Setelah diketahui ukuran sampel yang digunakan selanjutnya ditentukan banyaknya sekolah yang dipakai sebagai sampel penelitian, distribusi banyaknya siswa dikelas III IPA pada sekolah SMA/MA di Kabupaten Maluku tengah Provinsi Maluku adalah 13 siswa.

Menentukan banyaknya sekolah yang menjadi sampel penelitian

$$
b s=\frac{n}{\text { Distribusi siswa pada sekolah }}
$$

Keterangan:

bs: Banyak sekolah

n: Jumlah siswa

$b s=\frac{95}{13}=7,30 \approx 7$

dengan demikian banyaknya sekolah yang digunakan dalam penelitian ini adalah sebanyak 7 sekolah.

Ketiga, setelah diketahui banyaknya sekolah yang dipakai. Setelah itu, menentukan banyaknya perwakilan pada setiap strata dengan menggunakan rumus sampel berstrata.

Dimana

$$
n_{i}=\frac{N_{i}}{N} \cdot n
$$

\footnotetext{
$n_{i}:$ Jumlah sampel menurut stratum $\mathrm{n}$ : Jumlah sampel seluruhnya

$N_{\tilde{i}}$ : Jumlah Populasi menurut stratum

$\mathrm{N}$ : Jumlah Populasi seluruhnya
}

Pemilihan sampel dengan stratified sampling ditentukan dengan mengelompokkan strata sekolah berdasarkan kelompok perolehan persentase penguasan materi soal matematika UN SMA Tahun Pelajaran 2010/2011 di Kabupaten Maluku tengah menjadi tiga kategori, yaitu: tinggi, sedang, dan rendah. Kualifikasi tinggi (rata-rata $\geq 75$ ), sedang (rata-rata $60 \leq U N<75$ ), rendah (rata-rata $<60$ ). Kriteria ini di ambil berdasarkan KKM pada umumnya di sekolah-sekolah SMA/MA di Kabupaten Maluku Tengah dimana Nilai 60 adalah nilai terendah KKM dari ke-53 sekolah dan nilai 75 adalah nilai tertinggi KKM dari ke-53 sekolah untuk tahun pelajaran 2010/2011.

Berdasarkan rentang tersebut dari 53 sekolah yang berkategori tinggi 34 sekolah, sedang 5 sekolah, dan rendah 14 sekolah. Jumlah sampel yang akan dipilih sebanyak 7 sekolah, sehingga besar masing-masing sampel untuk kategori tinggi, sedang, dan rendah diperoleh dengan cara sebagai berikut:

$$
\begin{aligned}
& \text { Tinggi }=\frac{34}{53} \times 7=4.49=4 \text { Sekolah } \\
& \text { Sedang }=\frac{5}{53} \times 7=0.66=1 \text { Sekolah } \\
& \text { Rendah }=\frac{14}{53} \times 7=1.84=2 \text { Sekolah }
\end{aligned}
$$

Tabel 1. Daftar Sekolah yang Menjadi Sampel Penelitian

\begin{tabular}{cccc}
\hline No & $\begin{array}{c}\text { Nama } \\
\text { Sekolah }\end{array}$ & $\begin{array}{c}\text { Jenis } \\
\text { Sekolah }\end{array}$ & $\begin{array}{c}\text { Strata } \\
\text { Sekolah }\end{array}$ \\
\hline 1 & SMA A & Swasta & Rendah \\
2 & SMA B & Negeri & Rendah \\
3 & SMA C & Negeri & Sedang \\
4 & SMA D & Negeri & Tinggi \\
5 & SMA E & Swasta & Tinggi \\
6 & SMA F & Negeri & Tinggi \\
7 & SMA G & Negeri & Tinggi \\
\hline
\end{tabular}

\section{Teknik Pengumpulan Data}

Analisis Dokumen

Langkah-langkah dalam menganalisis yaitu, (1) Menentukan irisan soal-soal yang daya serapnya rendah dalam UN 2010-2011, (2) membuat soal uraian sebanyak 10 butir soal yang setara dengan soal UN, (3) melaksanakan tes tulis, (4) menganalisis lembar jawaban siswa.

Wawancara.

Metode ini digunakan jika dalam menyelesaikan tes uraian peneliti kurang mendapatkan informasi dari hasil jawaban siswa. Wawancara dilakukan jika jawaban dari hasil tes tulis siswa tidak terbaca kesalahan yang dilakukan siswa.Wawancara dilakukan secara terbuka tidak terstruktur dan merekam hasil Tanya jawab antar peneliti dengan subjek kemudian mencatat hal-hal yang penting.

\section{Instrumen Pengumpulan Data}

Instrumen dalam penelitian ini adalah soal bentuk soal uraian sebanyak 10 butir soal setara Ujian Nasional (Lihat Lampiran 1 Hal. 15) dan pedoman wawancara.

\section{Teknik Analisa Data}

Analisis data dilakukan selama dan setelah pengumpulan data, agar data yang diperoleh tersusun secara sistematis dan lebih mudah menafsirkan sesuai dengan rumusan masalah. Langkah-langkah analisis dan penafsiran data dilakukan dengan tahapan sebagai berikut. 
Pertama, mengumpulkan dan memformulasikan semua data yang diperoleh dari lapangan.

Kegiatan ini dilakukan dengan: (a) Memeriksa hasil tes (benar atau salah atau tidak mengerjakan); (b) Menganalisis hasil tes berdasarkan indikator-indikator yang telah ditetapkan; (c) Mengidentifikasi kesulitan subjek; (d) Mengelompokkan jenis kesulitan yang ditemukan pada saat siswa menyelesaikan soal tes menjadi 4 jenis kesulitan; (e) Melakukan wawancara terhadap subjek; (f) Mengelompokkan jenis kesulitan yang ditemukan pada saat wawancara; (g) Menganalisis hasil wawancara.

Kedua, menganalisis jenis kesulitan siswa yakni kesulitan menggunakan fakta, kesulitan dalam ketrampilan, kesulitan memahami konsep dan kesulitan menerapkan prinsip pada setiap item soal, untuk menentukan faktor yang mempengaruhi kesulitan siswa dilihat dari kesalahan yang dilakukan siswa dalam menyelesaikan soal. Kegiatan yang dilakukan pada tahap ini dalah dengan menentukan faktor yang mempengaruhi kesulitan siswa berdasarkan jenis kesulitan yang ditemukan dari hasil tes dan wawancara.

Ketiga, menarik kesimpulan. Pada tahap ini diadakan penarikan kesimpulan berdasarkan analisis terhadap data yang telah dikumpulkan, baik melalui tes maupun wawancara.

Penarikan kesimpulan ini meliputi: (a) Jenis kesulitan siswa dalam menyelesaikan soalsoal matematika pada UN tahun pelajaran 2010/ 2011 di Kabupaten Maluku Tengah; (b) Faktor kesulitan siswa dalam menyelesaikan soal-soal matematika pada UN tahun pelajaran 2010/2011 di Kabupaten Maluku Tengah.

Berdasarkan analisis tersebut, maka diadakan penafsiran data. Setiap hasil analisis data ditafsirkan untuk mendapatkan suatu kesimpulan penelitian.

\section{HASIL PENELITIAN DAN PEMBAHASAN}

Data yang diperoleh dari penelitian ini terdiri atas dua jenis yaitu data kuantitatif dan data kualitatif. Teknik analisis data yang digunakan adalah teknik analisis data kualitatif dengan data kuantitatif dan data kualitatif. Analisis data kuantitatif dilakukan dengan memeriksa jawaban peserta tes dilanjutkan dengan menghitung banyaknya kesalahan yang dilakukan oleh peserta tes dalam menyelesaikan soal. Dalam pemeriksaan jawaban, pemberian nilai tidak menjadi fokus utama dalam penelitian ini, tapi lebih diprioritaskan pemeriksaan jawaban terhadap jawaban peserta dengan memberikan kode untuk mengetahui benar salahnya. Kode $\mathrm{T}$ untuk jawaban benar, kode F untuk jawaban salah, dan kode NA untuk soal yang tidak menjawab sama sekali. Kode ini dimaksudkan untuk memudahkan merekap banyaknya kesalahan yang dilakukan siswa.

Tabel 2. Hasil Jawaban Ditinjau dari Strata $(n=95)$

\begin{tabular}{cccccc}
\hline & & \multicolumn{3}{c}{ Jawaban } & Jumlah \\
\cline { 3 - 6 } No & Strata & NA & F & T & $\begin{array}{c}\text { yabang } \\
\text { ditelaah }\end{array}$ \\
\hline 1 & Rendah & 143 & 112 & 5 & 260 \\
2 & Sedang & 27 & 90 & 23 & 140 \\
3 & Tinggi & 76 & 358 & 116 & 540 \\
& Total & 246 & 560 & 144 & 950 \\
\hline
\end{tabular}

Berdasarkan Tabel 2 tersebut menunjukkan bahwa dari jawaban 95 siswa, dimana setiap siswa mengerjakan 10 soal sehingga total jawaban yang ditelaah 950 jawaban. Pada strata rendah persentase jawaban siswa benar sebesar $1,92 \%$, jawaban salah sebesar $43,08 \%$, dan tidak menjawab $55 \%$. Pada strata sedang persentase jawaban siswa benar sebesar 16,43\%, jawaban salah sebesar 64,29\%, dan tidak menjawab $19,29 \%$. Pada strata tinggi persentase jawaban siswa benar sebesar 21,09\%, jawaban salah sebesar $65,09 \%$, dan tidak menjawab $13,82 \%$. Berikut histogram persentase jawaban siswa.

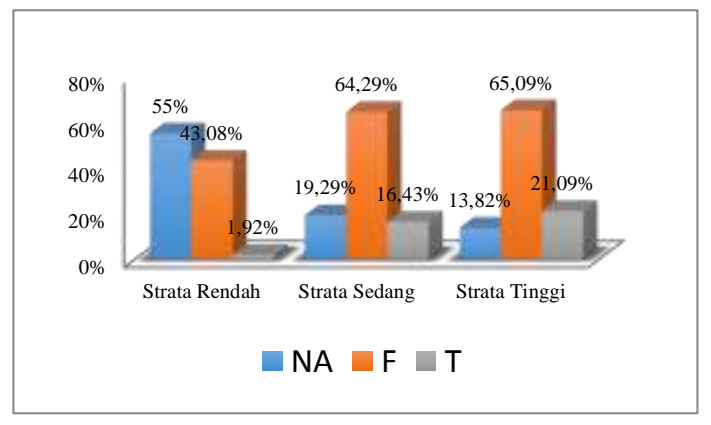

Gambar 1 Histogram Persentase Jawaban Siswa Menurut Strata

Tabel 2 merupakan data mentah yang berasal dari 7 sekolah yang dipilih berdasarkan kriteria yang telah ditentukan sebelumnya. Pada tabel ini peneliti menampilkan secara keseluruhan jumlah soal yang tidak dijawab, jawabannya salah dan benar. Sebagaimana pada pada Tabel 3. 
Tabel 3 Hasil Jawaban 95 Siswa dalam Menyelesaikan 10 Soal Matematika

\begin{tabular}{clcc}
\hline No & \multicolumn{1}{c}{ Jawaban } & Jumlah & \% \\
\hline 1 & Benar & 144 & 15,16 \\
2 & Salah & 560 & 58,95 \\
3 & Tidak Menjawab & 246 & 25,89 \\
& Jumlah & 950 & 100 \\
\hline
\end{tabular}

Tabel 3 menunjukkan bahwa terdapat 950 jawaban yang ditelaah diperoleh dari 95 siswa, dimana setiap siswa mengerjakan 10 soal. Persentase jawaban siswa benar sebesar 9,89\%, jawaban salah sebesar $58,21 \%$, dan tidak menjawab 31,89\%.

Selanjutnya untuk mengetahui persentase jawaban siswa untuk setiap soal dapat disajikan pada Gambar 2.

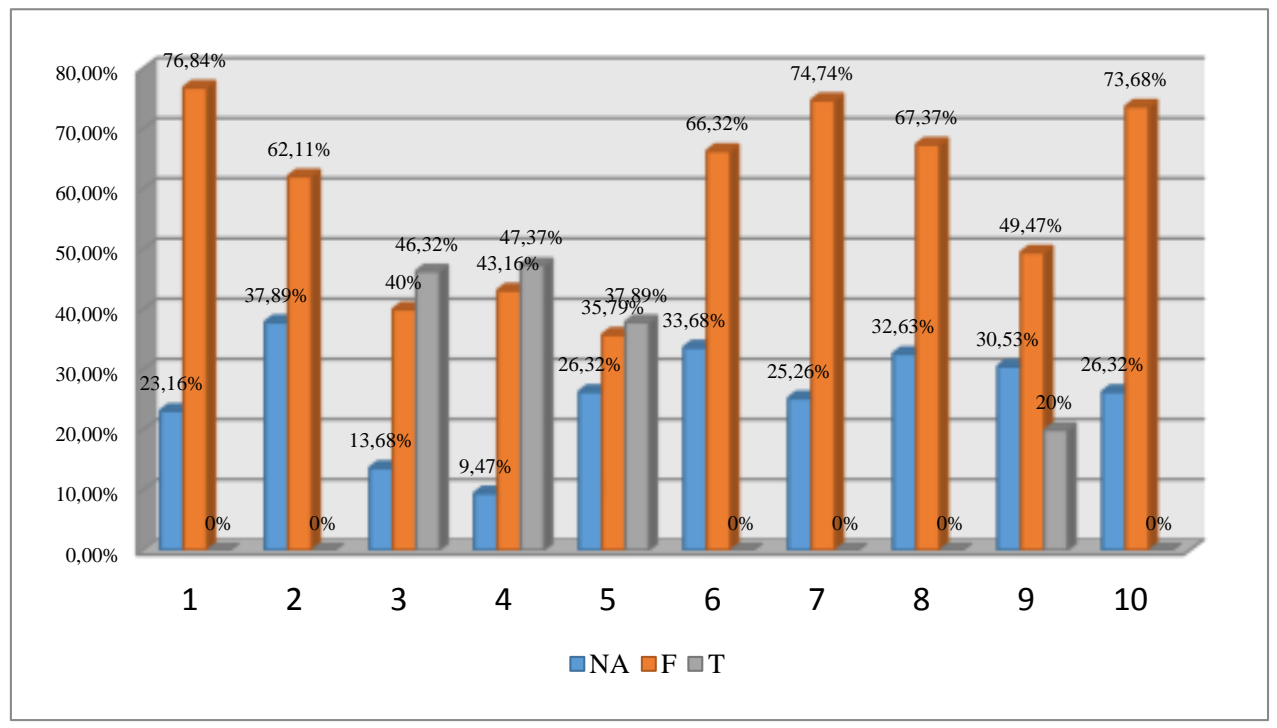

Gambar 2. Persentase Jawaban 95 Siswa untuk Setiap Soal

Hasil analisis data kualitatif diperoleh dengan melihat langkah-langkah penyelesaian soal yang telah dikerjakan siswa melalui tes dan dipadukan dengan hasil wawancara, guna menelusuri jenis kesulitan yang dilakukan siswa dan faktor yang mempengaruhi kesalahan tersebut.

Dari hasil tes dan wawancara dapat ditentukan jenis-jenis kesalahan siswa dalam menyelesaikan 10 soal matematika berdasarkan kompetensi yang sulit dicapai pada UN tahun 2011/2012 di Kabupaten Maluku Tengah. Secara umum jenis kesalahan akan disajikan pada Tabel 4

Tabel 4 Jawaban 95 Siswa Menurut Jenis Kesulitan

\begin{tabular}{clccc}
\hline No & $\begin{array}{c}\text { Jenis } \\
\text { Kesulitan }\end{array}$ & $\begin{array}{c}\text { Banyak } \\
\text { Kesalahan }\end{array}$ & $\begin{array}{c}\text { Banyak } \\
\text { Jawaban }\end{array}$ & \% \\
\hline 1 & $\begin{array}{l}\text { Kesulitan fakta } \\
\text { Kesulitan }\end{array}$ & 246 & 950 & 25,89 \\
2 & $\begin{array}{l}\text { ketrampilan } \\
\text { kesulitan }\end{array}$ & 559 & 950 & 41,16 \\
3 & $\begin{array}{l}\text { Konsep } \\
\text { Kesulitan } \\
\text { prinsip }\end{array}$ & 778 & 950 & 58,84 \\
\hline
\end{tabular}

Tabel 4 menunjukkan jenis kesulitan siswa dengan menelaah 950 jawaban siswa. Adapun jenis kesulitan yaitu kesulitan fakta sebesar 25,89\%, kesulitan ketrampilan 41,16\%, kesulitan konsep 58,84\%, Kesulitan prinsip $81,89 \%$.

Persentase jenis kesalahan siswa disajikan pada Gambar 3

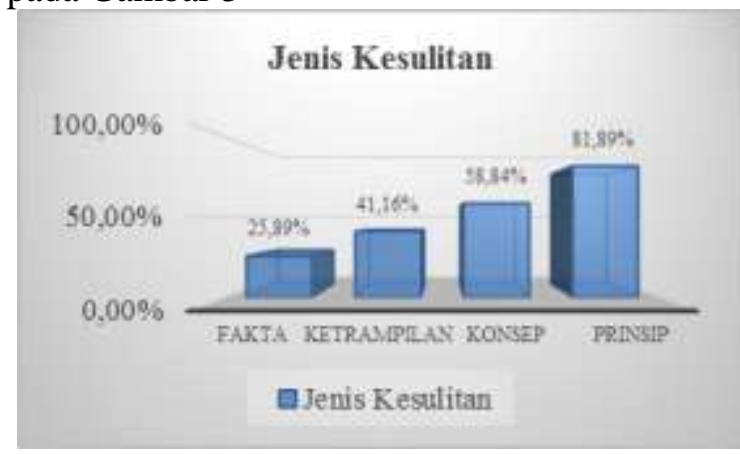

Gambar 3 Diagram Persentase Jenis Kesulitan 95 Siswa

Pada Gambar 3 terlihat kesulitan siswa ditinjau dari strata sekolah, menunjukkan jenis kesulitan pada setiap strata yang dialami oleh 95 siswa. Persentase kesulitan fakta untuk strata rendah sebesar $49,23 \%$ untuk strata sedang sebesar $31,43 \%$, sedangkan untuk strata tinggi sebesar $13,45 \%$. Persentase Kesulitan ketrampilan untuk strata rendah sebesar $63,85 \%$ untuk strata sedang sebesar $47,51 \%$, sedangkan untuk 
strata tinggi sebesar 29,27\%. Persentase Kesulitan konsep untuk strata rendah sebesar $81,54 \%$, untuk strata sedang sebesar $61,86 \%$, sedangkan untuk strata tinggi sebesar $47,09 \%$. Persentase kesulitan prinsip untuk strata rendah sebesar $98,08 \%$, untuk strata sedang sebesar $83,57 \%$, sedangkan untuk strata tinggi sebesar 79,09\%.

Setelah mengetahui jenis kesulitan siswa selanjutnya akan ditentukan faktor-faktor yang menyebabkan kesulitan siswa dalam menyelesaikan soal UN. Setiap soal yang diteskan selain memiliki jenis kesalahan yang berbeda-beda, soal tersebut juga memiliki faktor-faktor yang berbeda pula yang dapat menyebabkan kesulitan.

Berdasarkan Tabel 2, hasil tes terhadap 95 siswa dalam menyelesaikan 10 soal UN, ditemukan bahwa kemampuan siswa dalam menyelesaikan soal sangat bervariasi pada setiap sekolah. selain itu, diketahui bahwa siswa sudah dapat merespon soal yang diberikan hal ini terlihat dari jumlah jawaban yang salah dan yang benar lebih banyak dibandingkan dengan yang tidak menjawab sama sekali sebagaimana terlihat pada gambar 1.

Pada sisi lain, dengan melihat kemapuan siswa dalam menjawab soal sebagaimana terlihat pada gambar 2 dapat diartikan bahwa soal UN yang termasuk sulit diselesaikan oleh siswa pada tahun pelajaran 2010/2011 di Kabupaten Maluku Tengah juga dirasakan sulit oleh siswa pada tahun pelajaran 2011/2012. Hal ini dibuktikan dengan hasil tes terhadap siswa kelas XII SMA/MA Program IPA, bahwa soal yang hanya mampu terjawab dengan benar sebanyak 144 atau $15,16 \%$ dari 950 jumlah soal yang dikerjakan. Jika dilihat berdasarkan strata seperti pada Tabel 3 dan Gambar 1 tercermin bahwa kemampuan siswa dalam menjawab soal yang diberikan dengan tepat linear menurut strata, dimana untuk persentase jawaban benar sebesar 1,92\%, sedang sebesar $16,43 \%$ dan strata tinggi $21,09 \%$. Pada jawaban yang salah strata dimana strata tinggi sebesar 65,09\%, strata sedang sebesar 64,29\% dan strata rendah sebesar $43,08 \%$. Sedangkan yang tidak menjawab sama sekali pada strata rendah sebesar 55\%, strata sedang 19,29 dan strata tinggi sebesar $13,82 \%$.

Hasil analisis dari Tabel 2, Tabel 3, dan Tabel 4 menunjukkan bahwa strata tinggi lebih tinggi dibandingkan strata sedang dalam hal tidak menjawab, siswa tidak menjawab pada umumnya disebabkan oleh perbedaan siswa memahami dan menyusun langkah-langkah dalam menyelesaikan soal. Dari hasil wawancara diketahui pula bahwa siswa pada strata tinggi tidak menjawab soal lebih disebabkan masalah teknis dalam penyelesaian, misalnya pada kemampuan menentukan integral tak tentu fungsi trigonometri, siswa dalam menjawab " $\int \sin ^{5} 2 x \operatorname{cox} 2 x d x^{n}{ }^{\prime}$ mengalami kesulitan dalam menentukan $\sin ^{5} 2 x$ atau $\cos 2 \mathrm{x}$ dalam pemisalan, setelah dijelaskan siswa mampu mengerjakan dengan benar. Gambar 4 menunjukan hasil tes siswa pada setiap strata dalam menyelesaikan soal, kesulitan tertinggi dalam menjawab soal dilakukan siswa pada strata sedang sebesar $76,42 \%$, kemudian disusul strata rendah sebesar $54,23 \%$, dan kemudian strata tinggi sebesar $52,18 \%$. Kemudian bagi siswa yang tidak mengerjakan sama sekali terjadi pada strata tinggi sebesar $45,77 \%$, kemudian disusul strata rendah sebesar $36,36 \%$, dan kemudian strata sedang sebesar $15 \%$ atau siswa tidak melakukan kesalahan sama sekali.

Hasil analisis dari 10 soal tes yang diujikan, telah diperoleh hasil bahwa setiap soal memiliki tingkat kesulitan yang berbeda-beda. Hal itu bisa dilihat pada Gambar 2. Dari hasil telaah jawaban siswa terdapat beberapa soal yang tidak dapat dijawab dengan benar yakni terletak pada Soal nomor 1,2,6,7,8 dan soal nomor 10. Pada soal peringkat pertama adalah soal nomor 1 didapatkan $100 \%$ siswa yang tidak dapat menjawab dengan benar. Peringkat kedua kesulitan soal terjadi pada soal nomor 9. Pada soal ini hanya $20 \%$ siswa yang mampu menjawab dengan benar, 49,47\% siswa lainnya salah dalam mengerjakan soal dan 32,63\% lainnya tidak mengerjakan soal sama sekali. Peringkat ketiga kesulitan soal terjadi pada nomor 5. Dari kedua nomor tersebut hanya ada $16,84 \%$ siswa yang mampu menjawab dengan benar. Peringkat keempat kesulitan soal terjadi pada nomor 4. Dari soal nomor 4 ini hanya ada $35,79 \%$ siswa yang mampu menjawab dengan benar, $62,11 \%$ siswa menjawab salah dan sisanya tidak dapat menjawab sekali. Peringkat kelima kesulitan soal terjadi pada soal nomor 3. Pada soal ini hanya $34,74 \%$ siswa yang mampu menjawab dengan benar. Sisanya $31,82 \%$ siswa salah dalam mengerjakan soal.

Berdasarkan hasil telaah 950 jawaban siswa secara garis besar dari 10 soal yang diujikan, jika dilihat dari strata diperoleh bahwa soal nomor 1 tingkat kesulitan yang sama dialami oleh semua strata. Soal nomor 2 juga sama dengan soal nomor 1 dimana tingkat kesulitan yang sama dialami oleh semua strata. Dalam mengerjakan soal nomor 1 dan 2 semua siswa dalam semua strata tidak dapat mengerjakannnya dengan 
benar atau dengan kata tingkat kesulitannya adalah $100 \%$. Kesulitan yang dialami siswa dalam mengerjakan soal yang diujikan sangat bervariasi.

Siswa pada setiap strata sekolah mengalami kesulitan dalam mengaplikasikan turunan trigonometri dalam menyelesaikan bentuk integral trigonometri hal ini disebabkan konsep turunan trigonometri siswa masih lemah demikian juga dalam membuat pemisalan yang merupakan salah satu langkah dalam menyelesaikan soal nomor 1 .

Soal nomor 2 merupakan soal yang memiliki kesulitan tertinggi, siswa yang tidak menjawab soal ini pada setiap strata adalah sebesar $67,68 \%$ artinya lebih dari setengah siswa tidak mampu menjawab sama sekali, setelah dilakukan wawancara diketahui bahwa siswa kesulitan dalam menterjemahkan gambar dalam bentuk matematika serta kesulitan dalam menentukan titik sudut yang ditanyakan dalam soal nomor 2 .

Kemampuan siswa dalam menjawab benar adalah $38,18 \%$, sedangkan siswa pada strata rendah sebagian besar tidak memiliki kemampuan dalam menyelesaikan soal nomor 3, hal ini terlihat dari Persentase siswa yang menjawab salah sebesar $69,23 \%$ dan yang tidak menjawab sama sekali $30,77 \%$, artinya pada soal ini keseluruhan siswa tidak mampu menjawab dengan benar, setelah dilakukan wawancara diketahui bahwa siswa mengalami kesulitan dalam menentukan langkah penyelesaian serta pemahaman siswa terhadap soal.

Kesulitan siswa dalam menyelesaikan soal nomor 3, yakni kesulitan fakta dalam menentukan hasil operasi faktorial dimana siswa menganggap bahwa hasil operasi dari (6-4)! adalah 2 bukan 2!, kesulitan dalam ketrampilan menentukan langkah-langkah penyelesaian dimana siswa lemah dalam penalaran dalam menentukan kombinasi banyaknya siswa dan banyaknya soal yang dipilih, kesulitan dalam memahami konsep kebanyakan dikarenakan siswa belum memahami dengan baik konsep kombinasi dan permutasi, sedangkan kesulitan menerapkan prinsip teletak pada kekeliruan siswa dalam operasi factorial.

Kemampuan siswa dalam menyelesaikan soal nomor 4 dan nomor 5 hampir sama dengan soal nomor 3 yakni banyaknya kesalahan yang dilakukan siswa linear menurut strata.

Kesulitan siswa dalam menyelesaikan soal nomor 4, yakni kesulitan fakta dalam menentukan nilai tempat $\mathrm{x}$ dan $\mathrm{y}$, kesulitan ketrampilan dalam menentukan persamaan garis sing- gung lingkaran melalui titik di luar lingkaran, kesulitan memahami konsep dalam mensubsitusikan nilai $\mathrm{x}$ dan $\mathrm{y}$, kesulitan dalam menerapkan prinsip dalam menggunakan rumus persamaan garis singgung lingkaran. Sedangkan kesulitan dalam menyelesaikan soal nomor 4 lebih disebabkan kesulitan dalam menerapkan prinsip yakni dalam menentukan operasi $(2 \sqrt{7})^{2}$ dari jawaban siswa diketahui bahwa siswa hanya mengkuadratkan bilangan 2 dan mengabaikan $\sqrt{7}$.

Pada soal nomor 6 dan 7 kesulitan siswa sebagaimana pada soal nomor 1 dan soal nomor 2 yaitu siswa tidak dapat menjawab dengan benar kedua soal ini, dimana siswa pada umumnya dapat merespon soal yang diberikan. Siswa yang tidak dapat menjawab melebihi $60 \%$, dari jawaban siswa juga diketahui penyebab kesulitan siswa pada umumnya akibat kesalahan-kesalahan mendasar pada aljabar sederhana.

Pada soal nomor 8 siswa yang menjawab benar sebanyak $0 \%$ artinya bahwa siswa pada semua strata tidak mampu menjawab dengan benar soal tersebut, disamping itu, terdapat hal yang menarik dari jawaban siswa, dimana siswa pada strata rendah jumlah siswa yang tidak dapat menjawab sebanyak $50 \%$ sedangkan siswa pada strata tinggi sebanyak $58,18 \%$, dari jawaban siswa diketahui bahwa siswa pada strata rendah pada umumnya dalam menjawab soal ini langsung mensubsitusikan nilai $\mathrm{x}$ pada limit $\lim _{x \rightarrow 0} \frac{1-\cos 2 x}{5 x^{2}}$ tanpa menyederhanakan terlebih dahulu setelah diketahui bahwa hasil dari subsitusi nilai $\mathrm{x}$ adalah bentuk tak tentu, hal ini disebabkan dari pemahaman konsep yang masih lemah pada siswa strata rendah, sedangkan siswa pada strata tinggi pada umumnya tidak menjawab soal yang diberikan disebabkan siswa kesulitan dalam menyederhanakan bentuk trigonometri padahal siswa telah memahami konsep trigonometri apabila dengan mensubsitusikan nilai $\mathrm{x}$ menghasilkan bentuk tak tentu maka bentuknya dapat disederhanakan dengan mencarikan faktor yang sama kemudian digunakan subsitusi langsung untuk memperoleh hasilnya hal ini diketahui setelah dilakukan wawancara.

Kesulitan siswa dalam menyelesaikan soal nomor 9 yakni dalam menentukan nilai optimum suatu fungsi, dimana siswa lebih cenderung menggunakan system persamaan linear sederhana untuk dua fungsi serta menentukan titik uji dengan menggunakan metode garis selidik. Sedangkan kesulitan soal nomor 10 terletak pada kesulitan siswa dalam mengoperasi- 
kan dua fungsi yang diketahui serta kesulitan memahami konsep dalam memetakan kedua fungsi.

Setelah mengetahui kesulitan yang dialami oleh siswa dalam menyelesaikan 10 soal yang diberikan selanjutnya adalah mengetahui faktor-faktor yang menyebabkan siswa mengalami kesulitan-kesulitan tersebut. Berdasarkan hasil analisis jenis kesulitan yang telah dilakukan sebelumnya, telah ditentukan faktor-faktor yang menyebabkan kesulitan siswa dalam menyelesaikan soal UN. Oleh karena itu pada bagian ini akan dibahas bahwa setiap soal memiliki faktor-faktor berbeda yang menyebabkan kesulitan. Hasil analisis soal nomor 1 untuk faktor-faktor yang menyebabkan kesulitan siswa telah didapatkan persentase yang berbeda-beda pada setiap stratanya. Dari 3 faktor yang menyebabkan kesulitan siswa, faktor siswa tidak menguasai turunan trigonometri dialami oleh semua siswa pada setiap strata atau $100 \%$ siswa mengalaminya. Untuk strata rendah faktor yang paling dominan setelah faktor siswa tidak menguasai turunan trigonometri adalah faktor siswa tidak menguasai teknik dalam integral tak tentu fungsi trigonometri yakni sebesar 84,62\% yang menyebabkan kesulitan siswa, dan siswa menganggap bahwa pangkat di dalam trigonometri adalah konstanta yang dapat dipindahkan didepan integral 15,38\%. Untuk strata sedang ada dua faktor lainnya yang menyebabkan kesulitan siswa selain faktor siswa tidak menguasai turunan trigonometri, yaitu siswa tidak menguasai teknik dalam integral tak tentu fungsi trigonometri sebesar $57,14 \%$, dan siswa menganggap bahwa pangkat di dalam trigonometri adalah konstanta yang dapat dipindahkan di depan integral sebesar $14,29 \%$. Sedangkan untuk strata tinggi terdapat dua lainnya sebagaimana pada strata rendah dan sedang, faktor yang menyebabkan kesulitan siswa, yaitu faktor siswa tidak menguasai turunan trigonometri, yaitu siswa tidak menguasai teknik dalam integral tak tentu fungsi trigonometri sebesar $57,14 \%$, dan siswa menganggap bahwa pangkat di dalam trigonometri adalah konstanta yang dapat dipindahkan didepan integral sebesar 14,29\%

Hasil analisis untuk soal nomor 2 diketahui untuk strata rendah terdapat tiga faktor yang menyebabkan kesulitan siswa. Yaitu Siswa tidak dapat menghitung nilai perbandingan trigonometri sudut antara garis dan bidang pada bangun ruang sebesar $100 \%$, siswa menganggap bahwa untuk menentukan nilai perbandingan trigonometri dapat dilakukan dengan penjumlah- an sudut-sudut sebesar $30,77 \%$, dan yang terakhir siswa salah dalam menentukan diagonal bidang dan diagonal ruang $15,38 \%$. Untuk strata sedang terdapat tiga faktor sebagaimana pada strata sedang yang menyebabkan kesulitan siswa, yaitu Siswa tidak dapat menghitung nilai perbandingan trigonometri sudut antara garis dan bidang pada bangun ruang sebesar $100 \%$ dan siswa menganggap bahwa untuk menentukan nilai perbandingan trigonometri dapat dilakukan dengan penjumlahan sudut-sudut dan siswa salah dalam menentukan diagonal bidang atau diagonal ruang sebesar 14,29\%. Sedangkan untuk strata tinggi ada dua faktor yang menyebabkan kesulitan siswa yaitu Siswa tidak dapat menghitung nilai perbandingan trigonometri sudut antara garis dan bidang pada bangun ruang sebesar $100 \%$ dan yang terakhir siswa salah dalam menentukan diagonal bidang dan diagonal ruang $7,27 \%$.

Hasil analisis untuk soal nomor 3 didapatkan untuk strata rendah ada tiga faktor yang menyebabkan kesulitan siswa yaitu siswa salah dalam menentukan banyaknya pilihan dan banyaknya cara dalam menyelesaiakan soal permutasi sebesar 69,23\% dan Siswa tidak dapat menyelesaikan masalah yang berkaitan dengan permutasi sederhana $30,77 \%$ serta siswa memahami soal kombinasi sebagai bentuk soal peluang sebesar $19,23 \%$. Untuk strata sedang hanya ada dua faktor yang menyebabkan kesulitan siswa yaitu siswa salah dalam menentukan banyaknya pilihan dan banyaknya cara dalam menyelesaikan soal permutasi sebesar $14,29 \%$ dan siswa tidak dapat menyelesaikan masalah yang berkaitan dengan permutasi sederhana sebesar $14,29 \%$. Dan untuk strata tinggi juga terdapat dua faktor yang menyebabkan siswa mengalami kesulitan dalam menyelesaikan soal ini dengan tepat yaitu siswa tidak dapat menyelesaikan masalah yang berkaitan dengan permutasi sederhana sebesar 9,09\% dan siswa salah dalam menentukan banyaknya pilihan dan banyaknya cara dalam menyelesaiakan soal permutasi sebesar $7,27 \%$

Hasil analisis untuk soal nomor 4 didapatkan untuk strata rendah ada empat faktor yang menyebabkan kesulitan siswa yaitu siswa salah dalam operasi penjumlahan dan pengurangan yaitu sebesar $15,38 \%$, siswa keliru dalam mensubsitusikan nilai $\mathrm{x}$ dan y yaitu sebesar $23,08 \%$, siswa tidak dapat menentukan persamaan garis singgung lingkaran dengan syarat tertentu sebesar $61,54 \%$, dan yang terakhir siswa dalam memahami bentuk soal persamaan garis 
singgung lingkaran dan persamaan garis singgung melalui titik di luar lingkaran menggunakan gradien sebesar $53,85 \%$. Untuk strata sedang ada tiga faktor yang menyebabkan kesulitan siswa yaitu siswa salah dalam operasi penjumlahan dan pengurangan yaitu sebesar 14,29\% dan siswa keliru dalam mensubsitusikan nilai $x$ dan y yaitu sebesar $14,29 \%$ serta siswa tidak dapat menentukan persamaan garis singgung lingkaran dengan syarat tertentu sebesar $57,14 \%$. Kemudian untuk strata tinggi ada tiga faktor yang menyebabkan kesulitan siswa yaitu siswa salah dalam operasi penjumlahan dan pengurangan yaitu sebesar $14,55 \%$, siswa keliru dalam mensubsitusikan nilai $\mathrm{x}$ dan $\mathrm{y}$ yaitu sebesar 9,09\%, siswa tidak dapat menentukan persamaan garis singgung lingkaran dengan syarat tertentu sebesar $38,18 \%$.

Hasil analisis untuk soal nomor 5 didapatkan untuk strata rendah terdapat empat faktor yang menyebabkan kesulitan siswa yaitu siswa menganggap bahwa volume prisma adalah luas segi tiga sebesar $7,69 \%$, siswa tidak mengetahui pendekatan sudut-sudut istimewa sebesar $34,62 \%$, siswa tidak menguasai kemampuan dasar dalam menghitung unsur dari segi banyak dengan menggunakan aturan cosinus sebesar 92,31\% dan siswa tidak mengoperasikan perpangkatan bentuk akar sebesar 34,62\%. Untuk strata sedang ada tiga faktor yang menyebabkan kesulitan siswa yaitu siswa siswa menganggap bahwa volume prisma adalah luas segi tiga sebesar $14,29 \%$, siswa tidak menguasai kemampuan dasar dalam menghitung unsur dari segi banyak dengan menggunakan aturan cosinus sebesar $28,57 \%$ dan siswa tidak mengetahui pendekatan sudut-sudut istimewa sebesar $14,29 \%$. Sedangkan untuk strata tinggi terdapat tiga faktor yang menyebabkan kesulitan siswa yaitu siswa yaitu siswa siswa menganggap bahwa volume prisma adalah luas segi tiga sebesar $14,55 \%$, siswa tidak menguasai kemampuan dasar dalam menghitung unsur dari segi banyak dengan menggunakan aturan cosinus sebesar $21,82 \%$ dan siswa tidak mengetahui pendekatan sudut-sudut istimewa sebesar $12,73 \%$

Hasil analisis untuk soal nomor 6 didapatkan untuk strata rendah ada lima faktor yang menyebabkan kesulitan siswa yaitu siswa keliru dalam menyederhanakan penyebut bentuk akar sebesar $61,54 \%$, siswa tidak menguasai konsep limit sebesar $7,69 \%$, siswa tidak memahami bentuk-bentuk penyederhanaan dalam aljabar sebesar $76,92 \%$, siswa tidak dapat menentukan nilai limit fungsi aljabar $100 \%$, siswa salah dalam melakukan operasi perkalian sebesar $38,46 \%$. Untuk strata sedang ada empat faktor yang menyebabkan kesulitan yaitu siswa keliru dalam menyederhanakan penyebut bentuk akar sebesar $42,86 \%$, siswa tidak memahami bentukbentuk penyederhanaan dalam aljabar sebesar $71,43 \%$, siswa tidak dapat menentukan nilai limit fungsi aljabar sebesar $100 \%$ dan siswa salah dalam melakukan operasi perkalian sebesar $28,57 \%$. Sedangkan untuk strata tinggi ada empat faktor yang menyebabkan kesulitan siswa yaitu siswa keliru dalam menyederhanakan penyebut bentuk akar sebesar $18,18 \%$, siswa tidak dapat menentukan nilai limit fungsi aljabar $100 \%$, siswa tidak memahami bentuk-bentuk penyederhanaan dalam aljabar sebesar 49,09\%.

Hasil analisis untuk soal nomor 7 didapatkan untuk strata rendah ada lima faktor yang menyebabkan kesulitan siswa yaitu siswa keliru dalam mengubah pecahan dan bentuk akar kedalam bentuk perpangkatan sebesar 73,08\%, siswa keliru dalam operasi perpangkatan sebesar $23,08 \%$, siswa tidak memahami konsep integral sebesar $61,54 \%$, siswa tidak memahami operasi bentuk aljabar sebesar 73,08 dan siswa tidak dapat menentukan integral tak tentu fungsi aljabar sebesar $100 \%$. Untuk strata sedang ada empat faktor yang menyebabkan kesulitan siswa yaitu siswa keliru dalam mengubah pecahan dan bentuk akar kedalam bentuk perpangkatan sebesar $85,71 \%$, siswa keliru dalam operasi perpangkatan sebesar $14,29 \%$, siswa tidak memahami operasi bentuk aljabar sebesar $57,17 \%$, dan siswa tidak dapat menentukan integral tak tentu fungsi aljabar sebesar $100 \%$. Sedangkan untuk strata tinggi ada empat faktor yang menyebabkan kesulitan siswa yaitu siswa keliru dalam mengubah pecahan dan bentuk akar kedalam bentuk perpangkatan sebesar $10,91 \%$, siswa keliru dalam operasi perpangkatan sebesar $9,09 \%$, siswa tidak memahami operasi bentuk aljabar sebesar $54,55 \%$ dan siswa tidak dapat menentukan integral tak tentu fungsi aljabar sebesar $100 \%$.

Hasil analisis untuk soal nomor 8 didapatkan untuk strata rendah ada empat faktor yang menyebabkan kesulitan siswa yaitu siswa tidak mengetahui nilai-nilai perbandingan trigonometri sebesar $30,77 \%$, siswa tidak mengetahui konsep limit 38,46\%, siswa tidak dapat menyederhanakan bentuk limit trigonometri dengan menggunakan rumus limit fungsi trigonometri sebesar $100 \%$ dan siswa tidak dapat menentukan nilai limit fungsi trigonometri $76,92 \%$. Untuk strata sedang ada tiga faktor yang menyebabkan kesulitan siswa yaitu siswa tidak mengetahui 
nilai-nilai perbandingan trigonometri sebesar $85,71 \%$, siswa tidak dapat menyederhanakan bentuk limit fungsi trigonometri dengan menggunakan rumus limit fungsi trigonometri sebesar $71,43 \%$ dan siswa tidak dapat menentukan nilai limit fungsi trigonometri $78,57 \%$. Sedangkan untuk strata tinggi ada tiga faktor yang menyebabkan kesulitan siswa yaitu siswa tidak mengetahui nilai-nilai perbandingan trigonometri sebesar $18,18 \%$, siswa tidak dapat menyederhanakan bentuk limit fungsi trigonometri dengan menggunakan rumus limit fungsi trigonometri sebesar $54,55 \%$ dan siswa tidak dapat menentukan nilai limit fungsi trigonometri $61,82 \%$.

Hasil analisis untuk soal nomor 9 didapatkan untuk strata rendah lima faktor yang menyebabkan kesulitan siswa yaitu siswa tidak dapat membuat model matematika sebesar $61,54 \%$, siswa menganggap bahwa menetukan nilai optimun dari fungsi objektif dapat diselesaikan dengan sistem persamaan linear dua variabel sebesar $76,92 \%$, siswa tidak dapat menentukan titik potong kedua garis sebesar $100 \%$, dan siswa tidak dapat menyelesaikan masalah yang berkaitan dengan nilai maksimum dan minimum sebesar $100 \%$. Untuk strata sedang ada lima faktor yang menyebabkan kesulitan siswa yaitu siswa tidak dapat membuat model matematika sebesar 42,86\%, siswa menganggap bahwa menentukan nilai optimun dari fungsi objektif dapat diselesaikan dengan sistem persamaan linear dua variabel sebesar 76,92\%, siswa keliru dalam menentukan uji titik-titik sudut sebesar $71,43 \%$, siswa tidak dapat menyelesaikan masalah yang berkaitan dengan nilai maksimum dan minimum sebesar $14,29 \%$, siswa tidak dapat menentukan titik potong kedua garis sebesar $28,57 \%$, dan siswa tidak dapat menyelesaikan masalaha yang berkaitan dengan nilai maksimum dan minimum sebesar $100 \%$. Sedangkan untuk strata tinggi lima faktor yang menyebabkan kesulitan siswa keliru dalam menentukan uji titik-titik sudut sebesar 71,43\%, kesulitan siswa yaitu siswa tidak dapat membuat model matematika sebesar $16,36 \%$, siswa menganggap bahwa menetukan nilai optimun dari fungsi objektif dapat diselesaikan dengan sistem persamaan linear dua variabel sebesar $16,36 \%$ dan siswa tidak dapat menyelesaikan masalah yang berkaitan dengan nilai maksimum dan minimum sebesar $81,18 \%$ serta siswa tidak dapat menentukan titik potong kedua garis sebesar $20 \%$.

Hasil analisis untuk soal nomor 10 didapatkan untuk strata rendah ada tiga faktor yang menyebabkan kesulitan siswa yaitu siswa tidak mengetahui teknik menentukan daerah asal $100 \%$ dan siswa salah dalam mensubsitusikan nilai $\mathrm{x}$ sebesar $46,15 \%$, serta siswa tidak dapat menentukan nilai hasil komposisi fungsi dari dua fungsi yang diketahui sebesar $100 \%$. Untuk strata sedang hanya tiga faktor yang menyebabkan kesulitan siswa yaitu siswa salah dalam mensubsitusikan nilai $\mathrm{x} 28,57 \%$, siswa tidak mengetahui teknik menentukan daerah asal $100 \%$, siswa tidak dapat menentukan nilai hasil komposisi fungsi dari dua fungsi yang diketahui sebesar $100 \%$. Sedangkan untuk strata tinggi hanya ada tiga faktor yang menyebabkan kesulitan siswa yaitu siswa tidak mengetahui teknik menentukan daerah asal $100 \%$ dan siswa salah dalam mensubsitusikan nilai x sebesar 16,36\%, dan siswa tidak dapat menentukan nilai hasil fungsi komposisi dari dua fungsi yag diketahui sebesar $34,55 \%$.

\section{SIMPULAN DAN SARAN}

\section{Simpulan}

Jenis kesulitan yang paling dominan dialami siswa SMA/MA dalam menyelesaikan soal Ujian Nasional di Kabupaten Maluku Tengah ditinjau dari objek kajian kesulitan menggunakan fakta, kesulitan dalam ketrampilan, kesulitan memahami konsep dan kesulitan dalam menerapkan prinsip berturut-turut adalah:

Pertama, (1) kesulitan menerapkan prinsip, (2) kesulitan menggunakan fakta, (3) kesulitan dalam ketrampilan, dan (4) kesulitan memahami konsep. Kedua, Jika ditinjau menurut strata sekolah, kesulitan yang dialami oleh siswa pada umumnya linier menurut strata. Sekolah pada strata rendah tingkat kesulitannya adalah yang tertinggi, sekolah pada strata sedang tingkat kesulitannya adalah sedang, sedangkan sekolah pada strata tinggi tingkat kesulitannya adalah yang terendah. Dari hasil penelitian menunjukkan kesulitan menggunakan fakta tertinggi dialami oleh strata rendah diikuti strata sedang kemudian strata tinggi. Kesulitan dalam ketrampilan tertinggi dialami oleh strata rendah diikuti strata sedang kemudian strata tinggi. Kesulitan memahami konsep tertinggi dialami oleh strata rendah diikuti strata sedang kemudian strata tinggi. Dan terakhir kesulitan menerapkan prinsip tertinggi dialami oleh strata rendah diikuti strata sedang kemudian strata tinggi.

Faktor-faktor kesulitan yang dialami siswa SMA/MA dalam menyelesaikan soal-soal UN berdasarkan kompetensi yang berdaya serap rendah dari hasil UN di Kabupaten Maluku 
Tengah dari dalam diri siswa adalah faktor yang berkaitan dengan menggunakan fakta, ketrampilan, memahami konsep dan menerapkan prinsip.

Pertama, faktor yang berkaitan dengan keterampilan yang ditemukan dalam penelitian yakni keterampilan dalam menyelesaikan soal turunan dalam trigonometri dan teknik integral, serta keterampilan dalam memahami gambar. Kedua, Faktor yang berkaitan dengan konsep yang ditemukan adalam penelitian yakni siswa tidak memahami konsep dalam teknik penyelesaian, banyaknya cara dan pilihan dalam menyelesaikan soal kombinasi, operasi hitung, persamaan garis singgung lingkaran, menggunakan aturan cosinus dalam menentukan volume bangun ruang, limit baik bentuk aljabar maupun trigonometri, membuat model matematika, daerah asal suatu fungsi komposisi. Ketiga, Faktor yang berkaitan dengan prinsip yang ditemukan adalam penelitian yakni siswa tidak dapat memadukan beberapa konsep yang diperlukan dalam menyelesaiakan soal Ujian Nasional serta kesulitan dalam menerapkan rumus. Keempat, Berdasarkan hasil wawancara ditemukan kesulitan siswa dalam diluar faktor kesulitan fakta, ketrampilan, konsep dan prinsip juga disebabkan oleh faktor (1) kurang teliti, (2) terkecoh dan (3) lupa.

\section{Saran}

Bagi Siswa

Saran yang ditujukan bagi siswa yaitu; (a) Memperbanyak latihan dalam menggunakan hubungan dari berbagai konsep dalam melatih ketrampilan siswa; (b) Latihan menyelesaiakan integral baik integral trigonometri dan aljabar; (c) Latihan untuk menentukan daerah asal dari suatu fungsi komposisi; (d) Latihan untuk menginterpetasikan gambar.

Bagi Guru

Guru diharapkan dapat meningkatkan profesionalisme baik dalam mengajar maupun menjelaskan kepada siswa, guru dituntut juga agar dapat menemukan metode mengajar yang tepat dalam menjelaskan materi kepada siswa.

\section{Bagi MGMP}

Mengoptimalkan kegiatan untuk mencari solusi dan memberi penguatan mengenai kompetensi yang sulit dicapai pada UN.

\section{PPPPTK}

Memfasilitasi guru untuk lebih memperdalam kompetensi yang sulit dan teknik mengajar di kelas.

\section{DAFTAR PUSTAKA}

Alfeld, P (2004). Understanding Mathematics. Utah: Departemen of Mathematics. University of Utah.Tersedia: http:/www math utah edu/-alfeld/math html. (November 2011).

Bell, F. H. (1981). Teaching and learning mathematics (in secondary school), Dubuque: Browm.

Ben-Zvi, R., \& Hofstein, A. (1996). Improving teaching ang learning in science and mathematics. Columbia: Teachers College

Bynner, J. and Parsons, S. (1997). It doesn't get any better: The impact of poor numeracy skills on the lives of 37-year-olds. London: Basic Skills Agency.

Bzufka, M.W., Hein, J. and Neumarker, K.J. (2000). Neuropsychological differentiation of subnormal arithmetic abilities in children. Europaean Child and Adolescent Psychiatry, 9, pp.65-76.

Blanco, L., \& Garotte, M. (2007). Difficulties in learning inequalities in students of first year of pre-university education in spain. EJMSTE, Vol 3, pp.221-229

Cawley, J. F. (1985). Practical mathematics appraisal of the learning disabled. Maryland: An Aspen Publication

Depdiknas. (2005). Peraturan Pemerintah Nomor 19, tentang Standar Nasional Pendidikan.

Goos, M. \& Stillman, G. \& Vale, C. (2007). Teaching secondary school mathematics: research and practice for the 21st century. Australia:Allen\& Unwin

Dowker, A. (2004). What works for children with mathematical difficulties. International Journals in Oxford University, $2-3$.

Gross-Tsur, V., Manor, O. and Shalev, R. (1996). Developmental dyscalculia: prevalence and demographic features. Developmental Medicine and Child Neurology, 38, 25-33. 
Henson, K. T., \& Eller, B. F. (1999). Educational psychology for effective teaching. Boston: Wadsworth Publishing Company

Jane Gloria, P. K. \& Zakaria, E. (2012). Mathematical difficulties among primary school students. Journal Faculty of Education, Universiti Kebangsaan Malaysia, 7, pp.1086-1092.

Kennedy, L. M., Tipss, S., \& Johnson, A. (2008). Guiding children's learning of mathematics. Boston: Thomson Wadsworth.

Luna, C. A, \& Fuscablo, L. G. (2002). Enhancement of student problem solving performance thtough mathematical symbolism. JRME, Vol 5., pp.1-11

Lewis, C., Hitch, G.J. \& Walker, P. (1994). The prevalence of specific arithmetical difficulties in 9-to 10-year-old boys and girls. Journal of Child Psychology and Psychiatry, 35, pp.283-292.

Muijs, D., \& Reynolds, D. (2008). Effective teaching evidence and practice. London: Sage Publications Ltd.

Polya, G. (1981). Mathematical discovery on understanding, learning, and teaching problem solving. Canada: John \& Sons.

Riduwan. (2010). Belajar mudah penelitian. Bandung: Alfabeta
Romberg, T. A., \& Kaput, J. J. (2009). Mathematics worth teaching, mathematics worth understanding. Dalam E. Fennema \& T.A. Romberg (Eds.), Mathematics classrooms that promote understanding (pp.3-18). Mahwah, NJ: Taylor \& Francis e-Library.

Romberg \& Shafer. (2007). Teaching and learning mathematics with understanding. Dalam E. Fennema \& T.A. Romberg (Eds.), Mathematics classrooms that promote understanding (pp.159-184). Mahwah, NJ: Taylor \& Francis eLibrary

Rose M.C \& Arline B.C. (2009). Uncovering student thinking in mathematics grades 6-12. California: Corwin Press.

Sloane, F.C. \& Kelly, A.E. (2003). Issues in high-stakes testing testing programs. Theory into practice, 42(1), 12-17.

Stecher, B.M. (2002). Consequences of largescale, high stakes testing on school and classroom practice. Dalam L.S. Hamilton, B.M. Stecher, \& S.P. Klein (Eds.), Making sense of test-based accountability in education. Santa Monica CA:RAND.

Skemp, R. (1971). The psychology of learning mathematics. Australia: Pelican books. 